\title{
The INSL3 gene is a direct target for the orphan nuclear receptor, COUP-TFII, in Leydig cells
}

\author{
Raifish E Mendoza-Villarroel ${ }^{1}$, Mickaël Di-Luoffo' ${ }^{1}$, Etienne Camiré', Xavier C Giner ${ }^{1,+}$ \\ Catherine Brousseau' and Jacques J Tremblay ${ }^{1,2}$ \\ ${ }^{1}$ Reproduction, Mother and Child Health, Centre de Recherche du Centre Hospitalier Universitaire de Québec, \\ CHUL Room T3-67, 2705 Laurier Boulevard, Québec, City, Québec, Canada G1V 4G2 \\ ${ }^{2}$ Department of Obstetrics, Gynecology, and Reproduction, Faculty of Medicine, Centre for Research in \\ Biology of Reproduction, Université Laval, Québec City, Québec, Canada G1V 0A6 \\ ${ }^{\dagger} X$ C Giner is now at Faculty of Pharmacy, University of Montréal, Montéal, Québec, Canada H3C 3J7
}

\author{
Correspondence \\ should be addressed \\ to J J Tremblay \\ Email \\ Jacques-J.Tremblay@ \\ crchul.ulaval.ca
}

\begin{abstract}
Insulin-like 3 (INSL3), a hormone produced by Leydig cells, regulates testicular descent during foetal life and bone metabolism in adults. Despite its importance, little is known about the molecular mechanisms controlling INSL3 expression. Reduced Ins/3 mRNA levels were reported in the testis of mice deficient for chicken ovalbumin upstream promoter-transcription factor II (COUP-TFII), an orphan nuclear receptor known to play critical roles in cell differentiation and lineage determination in several tissues. Although COUP-TFII-deficient mice had Leydig cell dysfunction and impaired fertility, it remained unknown whether Ins/3 expression was directly regulated by COUP-TFII. In this study, we observed a significant decrease in Ins/3 mRNA levels in MA-10 Leydig cells depleted of COUP-TFII. Furthermore, a - $1087 \mathrm{bp}$ mouse Ins/3 promoter was activated fourfold by COUP-TFII in MA-10 Leydig cells. Using 5' progressive deletions, the COUP-TFII-responsive element was located between -186 and $-79 \mathrm{bp}$, a region containing previously uncharacterised direct repeat 0-like (DRO-like) and DR3 elements. The recruitment and direct binding of COUP-TFII to the DRO-like element were confirmed by chromatin immunoprecipitation and DNA precipitation assay respectively. Mutation of the DR0-like element, which prevented COUP-TFII binding, significantly decreased COUP-TFII-mediated activation of the $-1087 \mathrm{bp}$ Ins/3 reporter in CV-1 fibroblast cells but not in MA-10 Leydig cells. Finally, we found that COUP-TFII cooperates with the nuclear receptor steroidogenic factor 1 (SF1) to further enhance Ins/3 promoter activity. Our results identify Ins/3 as a target for COUP-TFII in Leydig cells and revealed that COUP-TFII acts through protein-protein interactions with other DNA-bound transcription factors, including SF1, to activate Ins/3 transcription in these cells.
\end{abstract}
Key Words
- insulin-like 3
- NR2F2
- nuclear receptor
- Leydig cells
- cooperation

Journal of Molecular Endocrinology (2014) 53, 43-55

\section{Introduction}

Insulin-like 3 (INSL3), also known as relaxin-like factor, belongs to the insulin-insulin-like growth factor-relaxin family of growth factors and hormones that was originally discovered by screening a boar testicular cDNA library
(Adham et al. 1993). The corresponding sequences were later obtained by screening genomic or cDNA libraries and by RT-PCR from humans (Burkhardt et al. 1994) and a variety of other species (Bathgate et al. 1996, Spiess et al. 1999, 
Zarreh-Hoshyari-Khah et al. 1999, Klonisch et al. 2001). In males, INSL3 is specifically produced by testicular Leydig cells from the onset of gonadal development throughout adulthood, whereas it is only secreted by the adult ovary (theca and luteal cells) in females (Zimmermann et al. 1997, Balvers et al. 1998). In foetal Leydig cells, INSL3 is strongly expressed from embryonic day 13.5 (E13.5) in mice (Zimmermann et al. 1997) and its expression decreases after birth with the disappearance of the foetal Leydig cell population (Zimmermann et al. 1997, Balvers et al. 1998). INSL3 levels in the adult Leydig cell population rise just before puberty, peak in adult animals and then decline in ageing animals (Pusch et al. 1996, Zimmermann et al. 1997, Balvers et al. 1998, O'Shaughnessy et al. 2002, Paust et al. 2002).

INSL3 plays important roles in male and female reproductive function. In males, INSL3 is involved in two very different, but critical, processes. During embryonic development, INSL3 was found to be a master regulator of gonadal descent, an essential step of the male sex differentiation process. Insl3 ${ }^{-/-}$null mice present bilateral cryptorchid testes, located high in the abdominal cavity close to the kidneys (Nef \& Parada 1999, Zimmermann et al. 1999). Furthermore, INSL3 expression in pancreatic $\beta$-cells of Insl3 null mice restored normal testis descent (Adham et al. 2002), while its expression in females led to descended ovaries (Adham et al. 2002, Koskimies et al. 2003). In adults, the role of INSL3 in males is not yet fully understood. INSL3 was found to be involved in bone metabolism (Ferlin et al. 2008) and proposed to act as a germ cell survival factor (Kawamura et al. 2004). In adult females, INSL3 plays a role in oocyte maturation and in follicle selection and survival (Spanel-Borowski et al. 2001, Irving-Rodgers et al. 2002, Kawamura et al. 2004).

Despite its crucial roles in reproductive development and function, surprisingly, very little is known about the mechanisms regulating Insl3 expression in Leydig cells. To date, only two transcription factors have been shown to regulate Insl3 promoter activity in Leydig cells: the nuclear receptors steroidogenic factor 1 (SF1, Ad4BP, NR5A1) and NUR77 (NGFI-B, NR4A1) (Zimmermann et al. 1998, Koskimies et al. 2002, Sadeghian et al. 2005, Tremblay \& Robert 2005, Robert et al. 2006). As these nuclear receptors are co-expressed in other cell types that do not produce INSL3, other transcription factors must participate in Insl3 transcription in Leydig cells.

The orphan nuclear receptor, chicken ovalbumin upstream promoter-transcription factor II (COUP-TFI, NR2F2), is strongly expressed in tissues originating from the mesenchyme and plays critical roles during mouse development (Tsai \& Tsai 1997, Lin et al. 2011). Coup-tfii null mice die before E10.5 due to angiogenesis and cardiovascular defects (Pereira et al. 1999). Temporal and tissues-specific Coup-tfii ablation in the stomach, limbs, diaphragm, uterus, and endothelial cells have revealed important roles in cell growth and differentiation and in organogenesis (Lee et al. 2004, Takamoto et al. 2005, You et al. 2005, Kurihara et al. 2007, Petit et al. 2007). It was previously reported that COUP-TFII might be involved in Insl3 expression (Qin et al. 2008). Indeed, inactivation of Coup-tfii during pre-pubertal stages of male development in mice led to a blockade in Leydig cell differentiation at the progenitor stage. This resulted in infertility, hypogonadism and spermatogenetic arrest due to defective testosterone synthesis in Coup-tfii ${ }^{-1-}$ male mice. A decrease in the expression of several genes (Hsd3b1, Cyp11a1 and Cyp17a1) required for testosterone biosynthesis was observed in these mice (Qin et al. 2008). A decrease in Insl3 mRNA levels was also reported (Qin et al. 2008). However, it remains unknown whether the decrease in gene expression, particularly Insl3, was due to a defect in the Leydig cell differentiation process and/or to a direct role of COUP-TFII in regulating their expression.

COUP-TFII regulates gene expression by binding to direct repeat (DR) motifs (AGGTCA) separated by variable spacing (from zero to six nucleotides) between the two halfsites (Pereira et al. 2000). Herein, we report that COUP-TFII directly and positively regulates Insl3 gene expression by binding to a previously uncharacterised DRO-like response element in the Insl3 promoter. In addition, we found that COUP-TFII cooperates with the nuclear receptor SF1 to further enhance Insl3 transcription.

\section{Materials and methods}

\section{Double immunohistochemistry}

Immunohistochemistry was done using an anti-COUPTFII antiserum (1:100, R\&D Systems, Minneapolis, MN, USA) and was carried out as described in Martin et al. (2008). For double immunodetection, the counterstaining with haematoxylin following COUP-TFII detection was omitted and replaced by the incubation with an antiINSL3 antiserum (1:100 dilution, M-122, Santa Cruz Biotechnology) overnight at $25^{\circ} \mathrm{C}$. The samples were washed twice with $1 \times$ PBS for 10 min each time and an alkaline phosphatase (ALKP)-conjugated secondary antibody (1:1000, Sigma-Aldrich Canada) was added and incubated for $1 \mathrm{~h}$ at $25^{\circ} \mathrm{C}$. Final detection was done using

Published by Bioscientifica Ltd 
an ALKP detection solution (Tris- $\mathrm{HCl} 0.1 \mathrm{M}, \mathrm{pH}$ 9.2, $1 \mathrm{mM}$ levamisole, naphthol $0.04 \%$ and Fast Blue BB diazonium salt $0.2 \%$ ). The negative control corresponds to the same procedures with the omission of anti-COUP-TFII antiserum (data not shown). All experiments were conducted according to the Canadian Council for Animal Care and have been approved by the Animal Care and Ethics Committee of Laval University (protocol \#2009011). Images were obtained using an Axioskop2 Plus microscope (Carl Zeiss Canada, Toronto, ON, Canada) and the ImagePro Plus Software (MediaCybernetics Rockville, MD, USA).

\section{siRNA transfection}

MA-10 Leydig cells were transfected with $150 \mathrm{nM}$ siRNA (Life Technologies) directed against Coup-tfii transcripts (sequence: ACU GGC CAU AUA UGG CAA UUC AAU A) or with a control non-targeting siRNA for $48 \mathrm{~h}$ using the JetPRIME Transfection Reagent according to manufacturer's protocol for siRNA transfection (PolyPlus, Illkirch, France). Three different siRNAs directed against different regions of COUP-TFII were used and they all decreased COUP-TFII protein levels, albeit with different efficacy. The one that decreased COUP-TFII protein by about $80 \%$ was chosen. Less than $10 \%$ difference was observed between scrambled siRNAs and no siRNA (data not shown). siRNA transfection had no effect on cell viability (Tripan Blue exclusion) and cell number.

\section{RNA isolation and real-time PCR}

Following siRNA treatment, RNA isolation and cDNA synthesis were carried out as previously described (Martin et al. 2008). Quantitative RT-PCR was carried out using a LightCycler 1.5 instrument and the LightCycler FastStart DNA Master SYBR Green I (Roche Diagnostics) according to the manufacturer's protocol. PCRs were carried out on Insl3 using the forward primer $5^{\prime}$-TGG CTA GAG CAG AGA CAT C- $3^{\prime}$ and the reverse primer $5^{\prime}$-CCT GTG GTC CTT GCT TAC- $3^{\prime}$ and under the following conditions: 10 min at $95^{\circ} \mathrm{C}$ followed by 35 cycles of denaturation $\left(5 \mathrm{~s}\right.$ at $95^{\circ} \mathrm{C}$ ), annealing $\left(5 \mathrm{~s}\right.$ at $\left.62^{\circ} \mathrm{C}\right)$ and extension $\left(20 \mathrm{~s}\right.$ at $\left.72^{\circ} \mathrm{C}\right)$ with single acquisition of fluorescence at the end of each extension steps. As internal control, PCRs were carried out using previously described Rpl19-specific primers and conditions (Martin et al. 2008). The specificity of the PCR products was confirmed by analysis of the melting curve and agarose gel electrophoresis. Quantification of gene expression was carried out using the Relative
Quantification Software (Roche Diagnostics) and is expressed as a ratio of Insl3:Rpl19 levels.

\section{Protein purification and western blotting}

After siRNA transfections, MA-10 Leydig cells were rinsed twice with ice-cold PBS and nuclear proteins were prepared as described previously (Martin et al. 2008). Protein concentrations were determined using standard Bradford assays. Nuclear proteins $(15 \mu \mathrm{g})$ were boiled $10 \mathrm{~min}$ in a denaturing loading buffer, fractionated by SDS-PAGE, and transferred onto nitrocellulose membrane (Bio-Rad). Immunodetection was carried out using a horseradish peroxidase coupled antibody approach according to the manufacturer's instructions (Amersham ECL and ECL Prime Western Blotting Detection Reagents, GE Healthcare Life Sciences, Baie-D'Urfé, QC, Canada). COUP-TFII and LAMIN B proteins were detected using a monoclonal anti-COUP-TFII antibody (1:1000, R\&D Systems) and an anti-LAMIN B antiserum (1:1000, C-20, Santa Cruz Biotechnology) respectively.

\section{Plasmids}

The -1087 to +5 bp murine Insl3 luciferase promoter construct was generated by PCR amplification from mice genomic DNA using the following set of oligonucleotide primers: forward containing a BamHI cloning site (italicised), 5'-GCG GAT CCT GGT TCC TAT GAT CTG GCT G-3' and reverse containing a KpnI cloning site (italicised), 5'-GGG GTA CCG TGG CAG GAG GCA GTG GGC AG-3'. Deletions to $-800,-600,-400,-333,-284,-234$, -186 and $-79 \mathrm{bp}$ were obtained by PCR using the -1087 bp Insl3 promoter as template, along with a common reverse primer mentioned earlier and the following forward primers containing a BamHI (italicised) cloning site: $-800 \mathrm{bp}, 5^{\prime}$-GCG GAT CCC CCT TGC TCC CCT GAC TGT G-3'; $-600 \mathrm{bp}, 5^{\prime}$-GCG GAT CCC TGG GAG AGT AGA GGT CTT G-3'; - 400 bp, 5'-GCG GATCCA ACA GGA AAG GAA CCA TTT A-3'; -333 bp, 5'-GCG GAT CCA AAC CAA GTC ATA AAT ACC TCC-3'; -284 bp, 5'-GCG GAT CCT CCA ACT CAC AGC AAT TCT CC-3'; $-234 \mathrm{bp}, 5^{\prime}$-GCG GAT CCA TGT GGG CTT CAC CCT TAC AAA GG-3'; - 186 bp, 5'-CGG GAT CCA ATG TTG GGG AGC GGC TCC TG-3' and -79 bp, 5'-GGG GAT CCT GCT GCT TGC CTG TGT TC-3'. All promoter fragments were cloned into a modified pXP1 luciferase reporter plasmid (Tremblay \& Viger 1999). The -1087 bp Insl3 reporter constructs harbouring inactivating mutations in both half-site of the DR0-like or of the DR3 elements were

Published by Bioscientifica Ltd. 
generated in a two-step process using the QuikChange XL Mutagenesis Kit (Stratagene, La Jolla, CA, USA) with the following oligonucleotides (mutated nucleotides are in bold, underlined and lowercase): first half-site mutation in DR3 (sense, 5'-CCT GGG AGA GGA CTT CAA aac aCC AAG CTG GAC ACA CAG C-3'; antisense, 5'-GCT GTG TGT CCA GCT TGG tgt tTT GAA GTC CTC TCC CAG G-3'), second half-site mutation in DR3 (both half-site mutated; sense, 5'-CCG CAC CTG GGA Get tAC TTC AAA ACA CC-3'; antisense, 5'-GGT GTT TTG AAG Taa gCT CCC AGG TGC GG-3'), first half-site mutation in DR0-like (sense, 5'-CCG TGA CTC GAG CCT Cac aaT TTT GGG TGC TGC TTG C-3'; antisense, 5'-GCA AGC AGC ACC CAA AAt tgt GAG GCT CGA GTC ACG G-3') and second half-site mutation in DR0-like (both half-sites mutated; sense, 5'-CCG TGA CTC GAG aag CAC AAT TTT GGG-3'; antisense, 5'-CCC AAA ATT GTG ctt CTC GAG TCA CGG-3'). The -1087 bp Insl3 reporter construct harbouring mutations in both DR0-like and DR3 elements was generated via the same two-step process using the -1087 bp Insl3 DR3 mutated construct as template and the sense and antisense oligonucleotides containing the mutations for the both half-site of the DR0-like element described above. The human -1137 bp INSL3 and rat -508 bp Insl3 promoter constructs have been described previously (Robert et al. 2006, Laguë \& Tremblay 2008). The mouse COUP-TFII expression vector (Pereira et al. 1999) was obtained from Dr Ming Tsai (Baylor College of Medicine, Houston, TX, USA). The mouse SF1 expression plasmid has been described previously (Tremblay \& Viger 2001). All plasmids were verified by sequencing (Centre de Génomique de Québec, CHUL Research Centre, Quebec City, QC, Canada).

\section{Cell culture, transfections and reporter assays}

Mouse MA-10 Leydig cells (Ascoli 1981), provided by Dr Mario Ascoli (University of Iowa, Iowa City, IA, USA) were grown in DMEM/F12 medium supplemented with $2.438 \mathrm{~g} / \mathrm{l}$ sodium bicarbonate, $3.57 \mathrm{~g} / \mathrm{l}$ HEPES, $15 \%$ horse serum and $50 \mathrm{mg} / \mathrm{l}$ of gentamicin and streptomycin sulfate. African Green monkey kidney fibroblast CV-1 cells were grown in DMEM medium supplemented with $3.7 \mathrm{~g} / \mathrm{l} \mathrm{HEPES}, 10 \%$ newborn calf serum and $50 \mathrm{mg} / \mathrm{l}$ of gentamicin and streptomycin sulfate. The MA-10 Leydig cells were originally derived from the mouse M5480P tumour (Ascoli 1981) and have since been well characterised. They produce steroids and respond to luteinizing hormone/human chorionic gonadotrophin (as well as Forskolin and cAMP) stimulation. The MA-10 Leydig cell line corresponds to the adult Leydig cells (reviewed in Rahman \& Huhtaniemi (2004)). The expression of Insl3 in MA-10 Leydig cells is similar to what has been reported in primary Leydig cell cultures and in rodents. For instance, Insl3 expression is known to be repressed by estradiol in vivo in mice and rats (Nef et al. 2000, Cederroth et al. 2007, Strauss et al. 2009, Zhou et al. 2011) and this repression was also observed in MA-10 Leydig cells (Laguë \& Tremblay 2009). Insl3 expression is upregulated by androgens in vivo (Zhou et al. 2010) as well as in primary Leydig cells and in MA-10 Leydig cells (Laguë \& Tremblay 2008, Tremblay et al. 2009). Therefore, the MA-10 Leydig cell line is an appropriate model to study Insl3 gene regulation in the adult Leydig cell population. MA-10 and $\mathrm{CV}-1$ cells were maintained at $37^{\circ} \mathrm{C}$ in $5 \% \mathrm{CO}_{2}$. MA-10 and CV-1 cells were transfected and lysates were analysed as described previously (Martin et al. 2008, 2009). Data reported represent the average of at least three experiments, each performed in triplicate. The cell passage number was lower than 35 for all experiments.

\section{Chromatin immunoprecipitation assay}

Chromatin immunoprecipitation (ChIP) assays were carried out essentially as described previously (Robert et al. 2006) with some modifications. Briefly, MA-10 Leydig cells were fixed with $1 \%$ formaldehyde at $20{ }^{\circ} \mathrm{C}$ for $10 \mathrm{~min}$. After harvesting in PBS, pelleted cells were washed for $10 \mathrm{~min}$ at $4{ }^{\circ} \mathrm{C}$ each time with buffer I $(0.25 \%$ Triton X-100, 10 mM EDTA, 0.5 mM EGTA, 10 mM HEPES and pH 6.5), buffer II (200 mM NaCl, 1 mM EDTA, $0.5 \mathrm{mM}$ EGTA, 10 mM HEPES and $\mathrm{pH}$ 6.5) and protease inhibitors. The samples were then centrifuged at $5900 \boldsymbol{g}$ for $5 \mathrm{~min}$ at $4{ }^{\circ} \mathrm{C}$. The pellets were resuspended (1\% SDS, $10 \mathrm{mM}$ EDTA, $50 \mathrm{mM}$ Tris, $\mathrm{pH}$ 8.0, protease inhibitors) and incubated on ice for $10 \mathrm{~min}$. The samples were next sonicated with the Misonix S-400 sonicator at $80 \%$ power and the lysates were centrifuged at $15700 \mathrm{~g}$. The supernatants were diluted and incubated at $4{ }^{\circ} \mathrm{C}$ for $2 \mathrm{~h}$ with $30 \mu \mathrm{l}$ of magnetic beads (Dynabeads, Life Technologies) which were previously blocked (with $0.2 \mu \mathrm{g} / \mu \mathrm{l}$ of sheared salmon sperm DNA and $0.5 \%$ BSA in PBS for $1 \mathrm{~h}$ at $4{ }^{\circ} \mathrm{C}$ ) along with $5 \mu \mathrm{g}$ of an antiNUR77 (M210, Santa Cruz Biotechnologies) antiserum (used as an immunoprecipitation positive control), an anti-COUP-TFII antiserum or non-specific immunoglobulin Gs (IgGs) (Santa Cruz Biotechnologies). The precipitates were washed four times in a rotating wheel with ChIP wash buffer (100 mM Tris, pH 7.4, $500 \mathrm{mM} \mathrm{LiCl,} \mathrm{1 \%} \mathrm{Igepal}$ and $1 \%$ sodium deoxycholate) for $5 \mathrm{~min}$ at $4{ }^{\circ} \mathrm{C}$ and once again with TE (10 mM Tris, pH 8 and $1 \mathrm{mM}$ EDTA).

Published by Bioscientifica Ltd. 
They were extracted with freshly prepared Elution buffer (1\% SDS and $0.1 \mathrm{M} \mathrm{NaHCO}_{3}$ ). The eluates were kept at $65^{\circ} \mathrm{C}$ overnight with $0.2 \mathrm{M} \mathrm{NaCl}$ to reverse the crosslinks. DNA was purified by phenol/chloroform extraction and ethanol precipitation and resuspended in $10 \mathrm{mM}$ Tris, $\mathrm{pH}$ 8. COUP-TFII-immunoprecipitated DNA fragments were analysed by PCR using primers specific for the proximal ( -225 to $-26 \mathrm{bp}$ ) (forward,: 5'-CCC TTA CAA AGG GGC GCT TGG C-3' and reverse, 5'-GGA TGC TCC TTA TAA CTG CCT CG-3') or distal ( -3133 to $-2923 \mathrm{bp}$ ) (forward, 5'-GGT ACA AGA CCA AGA CTC CAG ACG TCA CG-3' and reverse, 5'-GGG GTA GTC CTG ACT AAG TTG AGA GGG G-3') region of the mouse Insl3 promoter. The PCRs were carried out on a $\mathrm{T}_{\text {gradient }}$ thermocycler (Biometra, Montreal Biotech, Dorval, Québec, Canada) using Vent polymerase (New England Biolabs, Whitby, ON, Canada) and under the following conditions: $5 \mathrm{~min}$ at $95^{\circ} \mathrm{C}$ followed by 40 cycles of denaturation $\left(60 \mathrm{~s}\right.$ at $\left.95^{\circ} \mathrm{C}\right)$, annealing (proximal region $30 \mathrm{~s}$ at $60^{\circ} \mathrm{C}$ and distal region $60 \mathrm{~s}$ at $64^{\circ} \mathrm{C}$ ) and extension $\left(30 \mathrm{~s}\right.$ at $72^{\circ} \mathrm{C}$ ). The specificity of the PCR products was confirmed by agarose gel electrophoresis and sequencing. Input DNA represents $10 \%$ of total DNA used for a ChIP experiment. ChIP results were confirmed by three separate experiments.

\section{DNA precipitation assays}

DNA precipitation assays were carried out with $30 \mu \mathrm{l}$ of streptavidin magnetic beads (Promega), which were washed twice with $1 \times \mathrm{B} \& W$ buffer $(5 \mathrm{mM}$ Tris, $\mathrm{pH} 7.5$, $0.5 \mathrm{mM}$ EDTA and $1 \mathrm{M} \mathrm{NaCl}$ ), and then $100 \mathrm{ng}$ of WT and mutated double-stranded biotinylated oligonucleotides were bound to the beads in $1 \times B \& W$ buffer for $1 \mathrm{~h}$ at room temperature (beads without oligonucleotides were used as a negative control). The beads were washed twice in $1 \times$ B\&W buffer, once with $1 \times$ binding buffer $(5 \%$ glycerol, $20 \mathrm{mM}$ Tris, pH 7.5, $1 \mathrm{mM}$ EDTA, $1 \mathrm{mM}$ dithiothreitol, $0.15 \%$ Triton X-100, $100 \mathrm{mM} \mathrm{NaCl}$ and $4 \mathrm{mM} \mathrm{MgCl}_{2}$ ) and blocked with $1 \%$ BSA and sperm salmon DNA $(0.2 \mathrm{mg} / \mathrm{ml})$ for $1 \mathrm{~h}$ at $4{ }^{\circ} \mathrm{C}$. The bound biotinylated oligonucleotides were then mixed with $10 \mu \mathrm{g}$ of poly (dI-dC) and $100 \mu \mathrm{g}$ of nuclear extracts from MA-10 Leydig cells in a total volume of $500 \mu \mathrm{l}$ of $1 \times$ binding buffer with protease inhibitors, and incubated for $2 \mathrm{~h}(1 \mathrm{~h} 30 \mathrm{~min}$ at $4{ }^{\circ} \mathrm{C}$ and $30 \mathrm{~min}$ at room temperature) with rotation, followed by five washes in $1 \times$ binding buffer. The bound proteins were then eluted in western blotting-loading buffer and analysed by SDS-PAGE. The following oligonucleotides were biotinylated, annealed with the corresponding non-biotinylated oligonucleotide and used as probes containing: i) the WT COUP-TFII highaffinity response element (underlined; Kliewer et al. 1992) 5'-AGC TTC AGG TCA GAG GTC AGA GAG CT-3'; ii) the mutated (shown in lowercase); COUP-TFII high-affinity response element $5^{\prime}$-AGC TTC Aaa TCA GAa aTC AGA GAG CT-3'; iii) the WT DR0-like from the Insl3 promoter 5'-CCG TGA CTC GAG CCT CGA CCT TTT GGG TGC-3'; iv) the mutated (shown in lowercase) DR0-like from the Insl3 promoter 5'-CCG TGA CTC GAG aaT CGA aaT TTT GGG TGC-3'; v) the WT DR3 element from the Insl3 promoter $5^{\prime}$-ACC TGG GAG AGG ACT TCA AGG TCC CAA GCT GGA-3' and vi) the mutated (shown in lowercase) DR3 element from the Insl3 promoter 5'-ACC TGG GAG Aaa ACT TCA Aaa TCC CAA GCT GGA-3'.

\section{Statistical analyses}

For all single comparisons between two experimental groups, paired Student's $t$-tests were carried out. For all statistical analyses, $P<0.05$ was considered significant. For multiple group comparisons, statistical analyses were done using one-way ANOVA followed by the NewmanKeuls post hoc test. All statistical analyses were done using the GraphPad Prism Software (GraphPad Software, Inc., La Jolla, CA, USA).

\section{Results}

\section{COUP-TFIl present in MA-10 Leydig cells regulates Ins/3 gene expression}

To determine whether COUP-TFII is present in INSL3expressing Leydig cells within the mouse testis, double immunohistochemistry was carried out on mice testis sections at E19.5 and post-natal day 32 (P32). As shown in Fig. 1A, at E19.5 COUP-TFII was detected in interstitial cells that were negative for INSL3 (red-brown nuclear staining, open arrowheads). On the other hand, P32, COUP-TFII and INSL3 (blue-purple cytoplasmic staining) were co-localised in interstitial Leydig cells (solid arrowheads). COUP-TFII was also detected in some peritubular cells at E19.5 and P32 that do not express INSL3 (arrows in Fig. 1A and B). Thus, COUP-TFII and INSL3 are co-expressed in adult Leydig cells but not in foetal Leydig cells of the mouse testis.

Next, to determine whether COUP-TFII is involved in Insl3 gene expression, MA-10 Leydig cells were transfected with siRNA directed against COUP-TFII or non-targeting siRNA, and Insl3 mRNA levels were determined by qPCR. COUP-TFII knockdown (to about 20\%) was confirmed by

Published by Bioscientifica Ltd. 


\section{COUP-TFII/INSL3}
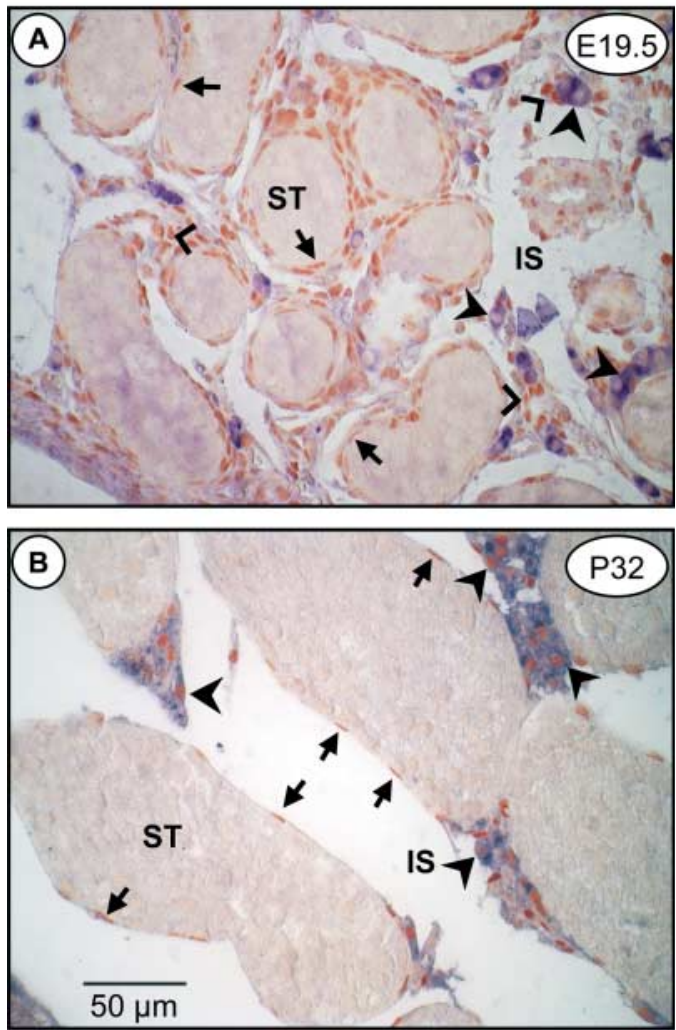

Figure 1

COUP-TFII co-localises with INSL3 in mouse adult Leydig cells. Double immunohistochemistry was carried out on (A) embryonic (E19.5) and (B) adult (P32) mouse testis sections using an anti-COUP-TFIl antiserum and an anti-INSL3 antiserum. COUP-TFII (red-brown staining) is present in the nuclei of interstitial cells (solid and open arrowheads). Leydig cells are positive for INSL3 (cytoplasmic blue-purple staining). COUP-TFII was also detected in the nuclei of some peritubular cells (arrows). Omission of the primary antibody served as negative control (data not shown). IS, interstitium; ST, seminiferous tubules. Magnification, 400×; scale bar, $50 \mu \mathrm{m}$.

western blotting (Fig. 2). In COUP-TFII-depleted MA-10 Leydig cells, Insl3 mRNA levels were decreased by $40 \%$ when compare with cells transfected with scrambled siRNAs (Fig. 2). Thus COUP-TFII contributes to the regulation of Insl3 expression in MA-10 Leydig cells.

In order to determine whether COUP-TFII could activate an Insl3 promoter construct and to avoid nonspecific activations, a dose-response assay was carried out. MA-10 Leydig cells were transfected with a -1087 and a $-79 \mathrm{bp}$ mouse Insl3 reporters in the presence of increasing doses of a COUP-TFII expression vector. As shown in Fig. 3, the -1087 bp mouse Insl3 promoter was activated (3.5- to 4.3 -fold) by COUP-TFII at all doses tested (25, 50, 125 and $250 \mathrm{ng})$. However, at $250 \mathrm{ng}$ the minimal -79 bp Insl3 reporter was significantly activated by about sevenfold (Fig. 3), which indicates non-specific effects at a dose of $250 \mathrm{ng}$. A dose of $50 \mathrm{ng}$ of COUP-TFII was therefore chosen as the optimal dose to significantly and specifically activate the $-1087 \mathrm{bp}$ Insl3 promoter.

\section{COUP-TFII activates the Ins/3 promoter via a novel DR0-like element at -97 bp}

To locate the COUP-TFII-responsive element, a series of $5^{\prime}$ progressive deletions of the mouse Insl3 promoter were transfected in MA-10 Leydig cells. As shown in Fig. 4, deletion from -1087 to $-186 \mathrm{bp}$ did not significantly impair COUP-TFII responsiveness. However, further deletion to $-79 \mathrm{bp}$ resulted in a substantial decrease in COUP-TFII-dependent activation (Fig. 4). These results indicate that a COUP-TFII-responsive element is likely located between -186 and $-79 \mathrm{bp}$. In silico analysis of this sequence revealed the presence of two previously uncharacterised DR elements, a DR0-like and a DR3, that could mediate the COUP-TFII-dependent activation of the
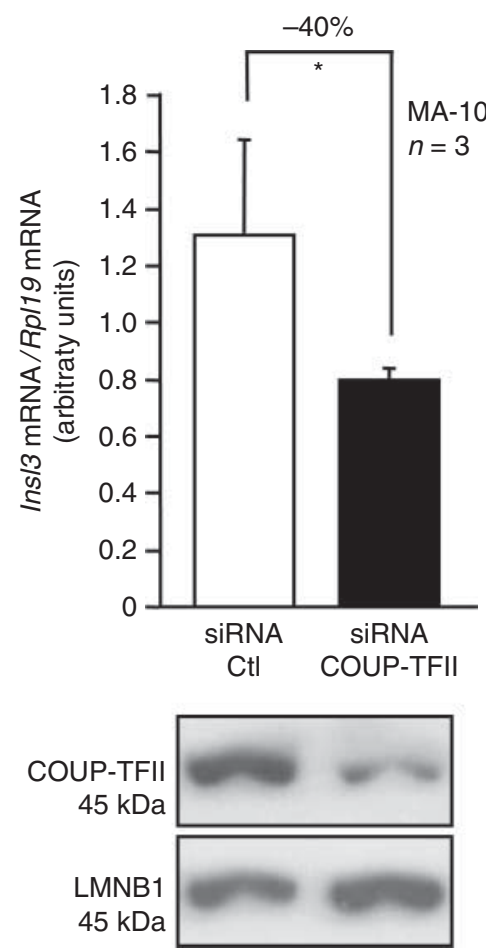

Figure 2

Knockdown of COUP-TFII in MA-10 Leydig cells decreases Ins/3 gene expression. MA-10 Leydig cells were transfected with $150 \mathrm{nM}$ of siRNA directed against COUP-TFII (black bar) or with a control non-targeting siRNA (open bar) for $48 \mathrm{~h}$. The cells were then harvested to obtain total RNA and nuclear extracts. Ins/3 mRNA levels were quantified by qPCR, while COUP-TFII protein levels were determined by western blotting. The qPCR results were corrected with the Rp/19 mRNA. An asterisk $\left({ }^{*} P<0.05\right)$ indicates a statistically significant difference from control. 

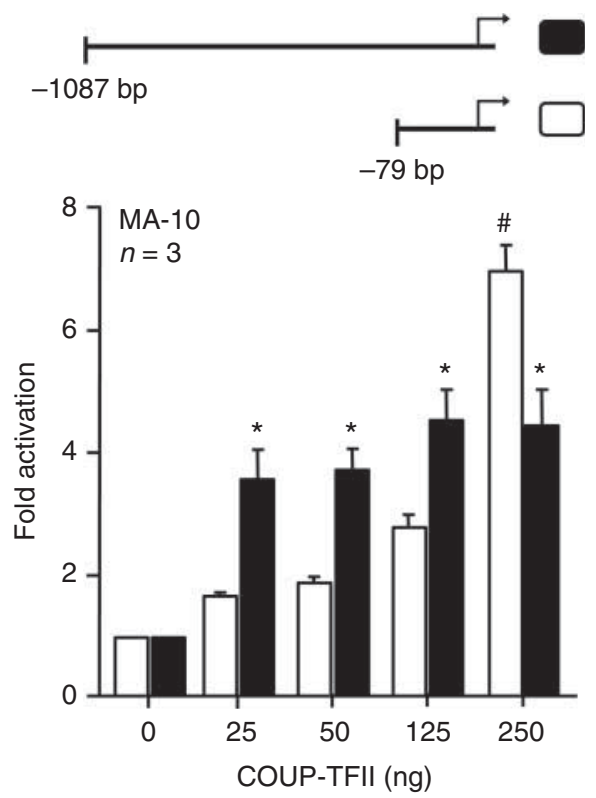

Figure 3

COUP-TFIl activates the mouse Ins/3 promoter. MA-10 Leydig cells were co-transfected with a -1086 to +5 bp (black bars) or a minimal -79 to $+5 \mathrm{bp}$ (open bars) mouse Ins/3 promoter construct along with an empty expression vector or different quantities (25, 50, 125 and $250 \mathrm{ng}$ ) of a COUP-TFII expression vector. Results are shown as fold activation over control ( \pm s.E.M.). An asterisk ( $\left.{ }^{*} P<0.05\right)$ and a hashtag $\left({ }^{*} P<0.05\right)$ indicate a statistically significant difference from control (no COUP-TFII) for a given reporter.

Insl3 promoter (Fig. 5A). Alignment of this sequence from different species (mice, rat, humans and bovine) revealed that the DR0-like element was well conserved in the Insl3 promoter of all species analysed, whereas the DR3 element was not (Fig. 5A). Consistent with this, COUP-TFII could equally activate the humans, rat and mice Insl 3 promoter in transient transfections of MA-10 Leydig cells (Fig. 5B).

To determine the contribution of the DRO-like and DR3 elements to Insl3 promoter activity, MA-10 Leydig cells and CV-1 heterologous fibroblast cells were transfected with various $-1087 \mathrm{bp}$ Insl3 reporter constructs either WT harbouring mutations in the DR0-like and/or the DR3 elements. As shown in the left panel of Fig. 6A, mutation of the DR3 element led to a 75\% decrease in Insl3 promoter activity in MA-10 Leydig cell. A mutation of the DR0-like element was more dramatic with a $93 \%$ reduction in Insl3 promoter activity, which is similar to what was observed with the minimal $-79 \mathrm{bp} \mathrm{Insl3}$ promoter. Mutation of both DR3 and DR0-like produced results identical to the DR0-like mutation (left panel of Fig. 6A). In CV-1 fibroblast cells, mutations of the DR3 and DRO-like elements also decreased Insl3 promoter activity, albeit to a much lesser extent than in MA-10 Leydig cells (right panel of Fig. 6A). These data indicate that the DR3 and DR0-like elements are both essential for maximal Insl3 promoter activity in MA-10 Leydig cells.

Next, we sought to determine whether the DR3 and/or the DRO-like elements were involved in the COUP-TFIIdependent activation of the Insl3 promoter. As shown in the left panel of Fig. 6B, mutation of the DR3 or the DR0-like individually or in combination (double DR3/DR1-like mutant) in the Insl3 promoter had no impact on COUP-TFII responsiveness in MA-10 Leydig cells. This could indicate that COUP-TFII activates the Insl3 promoter in association with other DNA-bound transcription factors in Leydig cells. In agreement with this, transfections in CV-1 fibroblast cells revealed that mutation of the DR0-like element at $-103 /-91 \mathrm{bp}$ abrogated COUP-TFII responsiveness while mutation of the DR3 element had no impact (right panel in Fig. 6B). This indicates that the DR0-like element is necessary for the COUP-TFII-mediated activation of the $-1087 \mathrm{bp}$ Insl3 promoter and that in MA-10 Leydig cells, COUP-TFII may act independently of DNA binding.

\section{COUP-TFII binds to the DRO-like element in the proximal Ins/3 promoter}

Next, ChIP assays were carried out to determine whether COUP-TFII was recruited to the proximal Insl3 promoter. Proteins were cross-linked to the chromatin, which was then sheared and immunoprecipitated using an antiCOUP-TFII antiserum. By PCR, a band of $\sim 200 \mathrm{bp}$ ( -225 to $-26 \mathrm{bp})$ was detected in the input sample (Fig. 7A, upper panel lane 4) as well as in the samples immunoprecipitated with the anti-COUP-TFII antiserum (Fig. 7A, upper panel lane 5) and with the anti-NUR77 antiserum (Fig. 7A, upper panel lane 7; used as a positive control). No bands were observed in the IgG control sample (Fig. 7A, upper panel lane 3). An upstream genomic region $(-3133$ to $-2923 \mathrm{bp})$ that does not contain any COUP-TFII binding site was also used (Fig. 7A, lower panel). No specific recruitment of COUP-TFII was observed on this distal region located at $\sim 3000 \mathrm{bp}$ upstream to the Insl3 transcriptional start site (Fig. 7A, lower panel lane 5) or when using an IgG as negative control (Fig. 7A, lower panel lane 3). COUP-TFII is thus recruited to the proximal Insl3 promoter in a native chromatin environment in MA-10 Leydig cells.

Although our ChIP data confirm the recruitment of COUP-TFII to the proximal Insl3 promoter, this approach cannot discriminate between direct DNA binding and indirect recruitment through protein-protein

Published by Bioscientifica Ltd. 


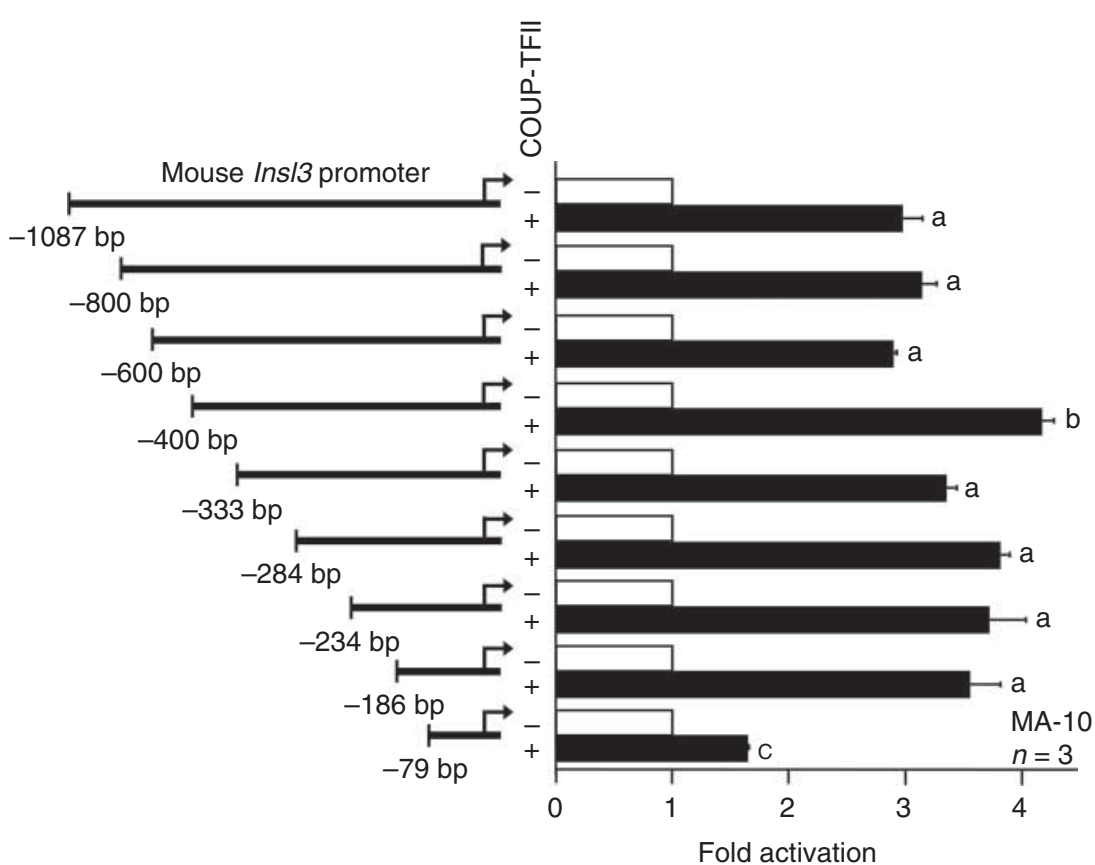

\section{Figure 4}

The COUP-TFII-responsive element is located within the proximal Ins/3 promoter. MA-10 Leydig cells were co-transfected with either an empty expression vector $(-$, open bars) or a COUP-TFII expression vector $(+$, black bars), along with a series of $5^{\prime}$ deletion constructs of the mouse Ins/3

interactions. Furthermore, our functional data (Fig. 6) suggest that COUP-TFII can act independently of DNA binding in MA-10 Leydig cells. Therefore, to determine whether COUP-TFII directly binds to the DR0-like element in vitro, we used a DNA precipitation approach. As shown in Fig. 7B, COUP-TFII was found to bind to oligonucleotides containing a high-affinity DR1 element (Fig. 7B, lane 3) as well as the DR0-like element from the Insl3 promoter (Fig. 7B, lane 5), but it did not bind the DR3 element from the Insl3 promoter (Fig. 7B, lane 7) or oligonucleotides harbouring mutations in these elements (Fig. 7B, lanes 4, 6 and 8). Taken together, these results indicate that COUPTFII directly and specifically binds to the DR0-like element in the proximal Insl3 promoter.

\section{COUP-TFII cooperates with SF1 on the Ins/3 promoter}

As our activation data (Fig. 6) indicate that COUP-TFII may act in association with other DNA-bound transcription factors and as the DR0-like element $(-103 /-91 \mathrm{bp})$ is in proximity to binding sites for the nuclear receptor SF1 (Zimmermann et al. 1998, Koskimies et al. 2002), one of which is located within the DR3 element $(-151 /-135 \mathrm{bp})$, we tested the possibility that these two nuclear receptors promoter as indicated. The number of experiments, each performed in triplicate, is indicated. Results are shown as fold activation over control $( \pm$ s.E.M.). A different letter indicates a statistically significant difference $(P<0.001)$.

might cooperate to modulate Insl3 promoter activity. Co-transfections in MA-10 Leydig cells revealed that COUP-TFII and SF1 individually activate the $-1087 \mathrm{bp}$ Insl3 promoter about fivefold while both nuclear receptors in combination had additive effects (left panel in Fig. 8). This cooperation was more apparent in heterologous CV-1 cells, where co-transfection of both COUP-TFII and SF1 led to a synergistic activation (about 30-fold) of the Insl3 promoter (right panel in Fig. 8).

\section{Discussion}

INSL3 is produced exclusively by the male foetus primarily to control the first phase of testicular descent (Ivell \& Anand-Ivell 2011). In adult males, INSL3 was identified as a major circulating testicular hormone that directly correlates with Leydig cell capacity and development (Ivell \& Anand-Ivell 2011, Ivell et al. 2013a). Recent evidence has identified a novel role for INSL3 in bone metabolism (Ferlin et al. 2008) in addition to its proposed role in the prevention of male germ cells apoptosis (Kawamura et al. 2004, Del Borgo et al. 2006, Amory et al. 2007). In adult females, despite its low expression compared with males, INSL3 was found to be a paracrine factor within the ovary

Published by Bioscientifica Ltd 
A

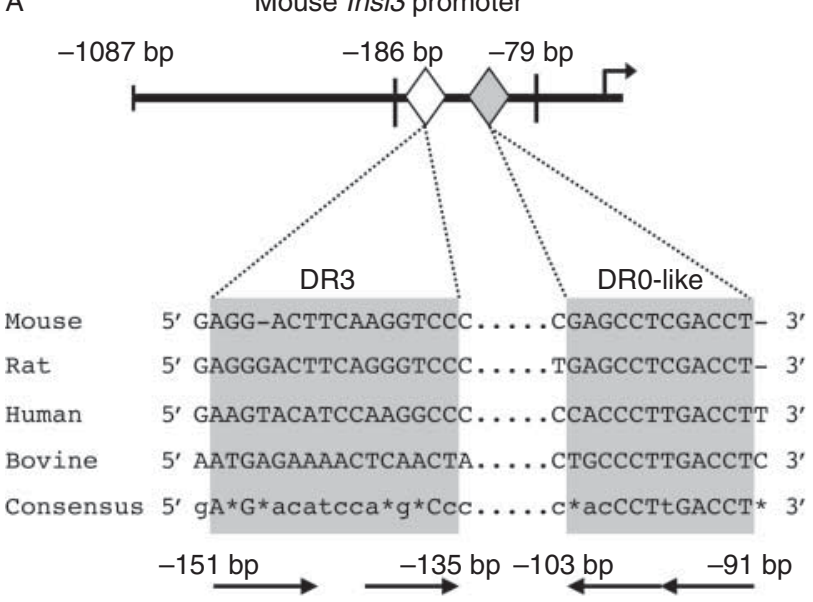

B

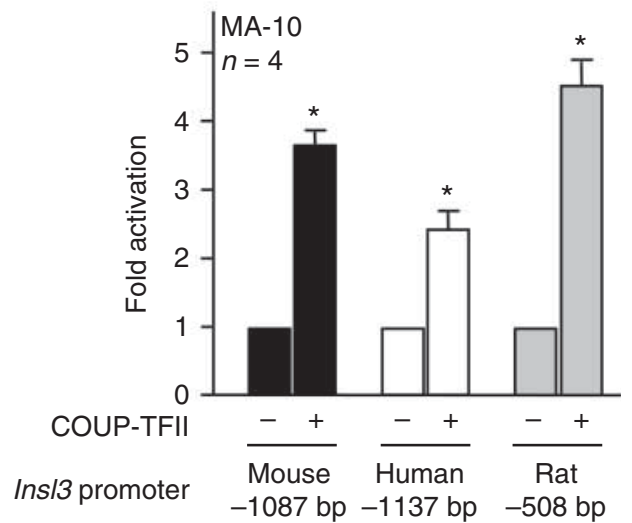

\section{Figure 5}

Species conservation of COUP-TFII responsiveness. (A) Sequence alignment of the two direct-repeat (DR) elements (grey shaded boxes) present in the Ins/3 promoter from the mice, rat, human and bovine. The DR3 element is located at $-143 \mathrm{bp}$ and the DR0-like element is located at $-97 \mathrm{bp}$ Conserved residues are indicated by capital letter while one mismatch is represented by a lowercase letter. Non-conserved residues are indicated by asterisks. The two potential DR elements are represented by the white

and may be involved in follicle selection and survival (Ivell $\&$ Anand-Ivell 2011). Despite these important physiological roles and the identification of INSL3 as a unique marker of Leydig cells, very little is known about the molecular mechanisms that regulate Insl3 expression in these cells.

INSL3 is constitutively expressed in Leydig cells and, unlike testicular steroids, it is regulated independently of the hypothalamo-pituitary-gonadal axis (Anand-Ivell
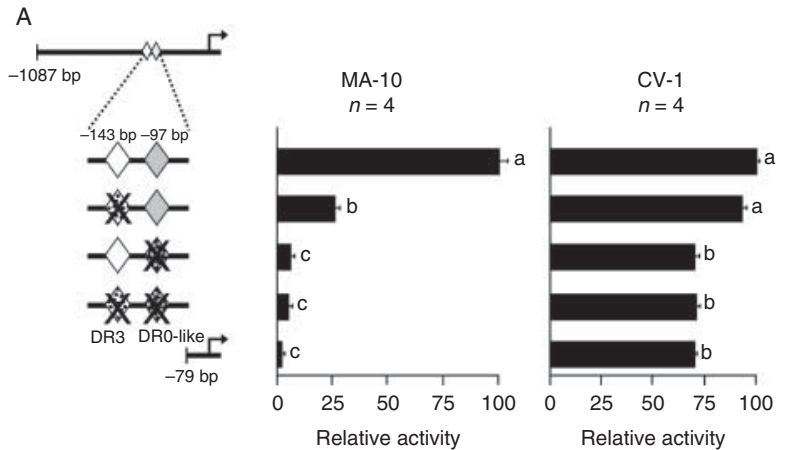

Figure 6

COUP-TFII activates the Ins/3 promoter via the DR0-like element at $-97 \mathrm{bp}$. (A) The DRO-like and DR3 elements are critical for Ins/3 promoter activity. MA-10 Leydig (left panel) and CV-1 fibroblast (right panel) cells were co-transfected with either a WT $-1087 \mathrm{bp}$ Ins/3 reporter, reporters harbouring mutations (depicted by a large X) in the DRO-like and DR3 elements as indicated, or a minimal $-79 \mathrm{bp}$ reporter. The two DR elements are represented by the white (DR3) and grey (DR0-like) diamonds. The number of experiments, each performed in triplicate, is indicated.
(DR3) and grey (DR0-like) diamonds. (B) MA-10 Leydig cells were co-transfected with either an empty expression vector $(-)$ or a COUP-TFII expression vector $(+)$, along the mice (black bars), human (open bars) or rat (grey bars) Ins/3 promoter as indicated. The number of experiments, each performed in triplicate, is indicated. Results are shown as fold activation over control ( \pm s.E.M.). An asterisk $(* P<0.05)$ indicates a statistically significant difference from control.

et al. 2006, Atlantis et al. 2009, Ivell \& Anand-Ivell 2009). This absence of direct hormonal regulation was also reported in studies of the rat and mice Insl3 gene promoter (Zimmermann et al. 1998, Koskimies et al. 2002). From these studies, a relatively short promoter region of $\sim 200$ bp was sufficient to drive Insl3 gene transcription in various Leydig cell lines. Within this proximal region, three binding sites for the transcription factor SF1 were

B

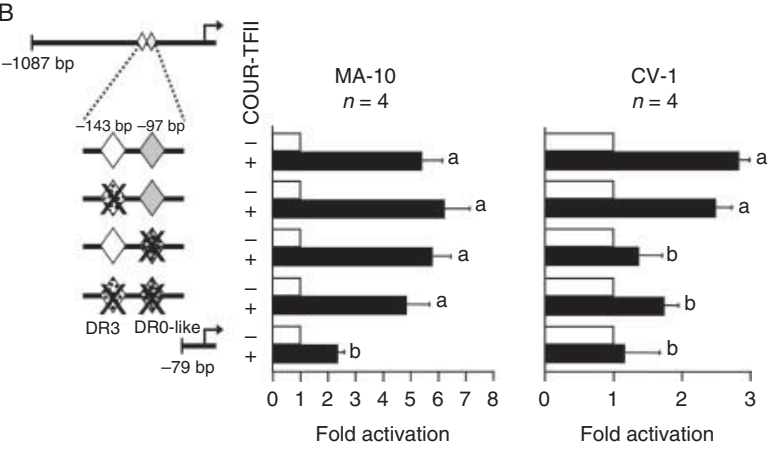

Results are shown as relative activity ( \pm s.E.M.). A different letter indicates a statistically significant difference $(P<0.001)$. (B) MA-10 Leydig (left panel) and CV-1 (right panel) cells were transfected with the same reporters described in A along with either an empty expression vector ( - , open bars) or an expression vector for COUP-TFII (+, black bars). The number of experiments, each performed in triplicate, is indicated. Results are shown as fold activation over control ( \pm S.E.M.). A different letter indicates a statistically significant difference $(P<0.001)$.

Published by Bioscientifica Ltd. 
A

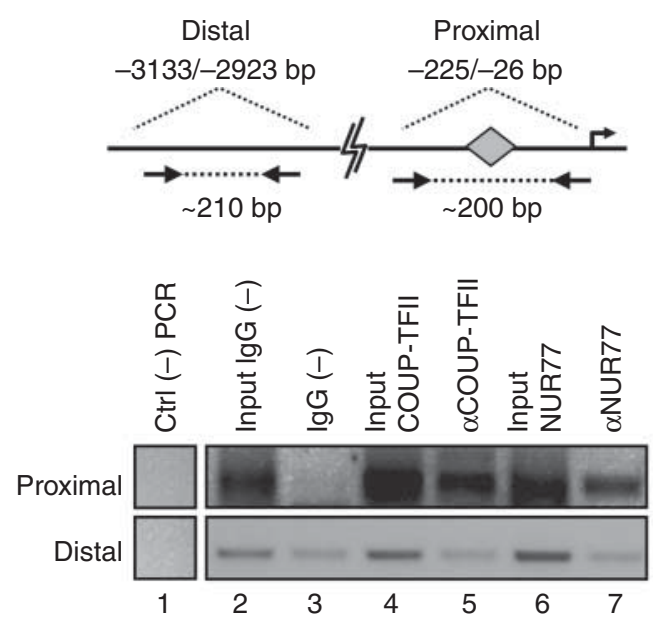

B

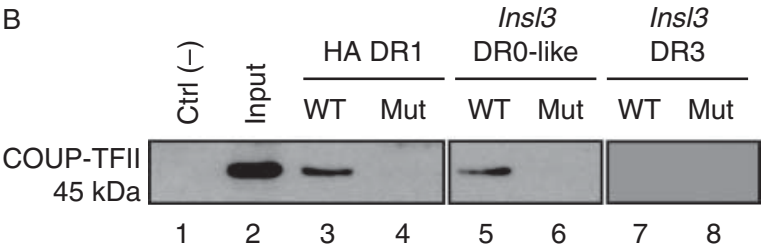

\section{Figure 7}

COUP-TFII is recruited to the proximal Ins/3 promoter and binds specifically to the DRO-like element. (A) COUP-TFII recruitment to the proximal Ins/3 promoter in MA-10 cells was determined by ChIP. An aliquot of chromatin preparation before immunoprecipitation (input) was used as positive control. A 200-bp DNA fragment containing the DR0-like element present in the mouse Ins/3 promoter was amplified by PCR in the input and in the sample immunoprecipitated with the anti-COUP-TFII antiserum but not in the IgG control sample. Recruitment of NUR77 in the same region was used as positive control. The recruitment of COUP-TFII and NUR77 was also assessed on the distal Ins/3 promoter region ( $-3000 \mathrm{bp})$ and the signals were similar to those of the IgG-negative control sample. Water was used as negative control for the PCR ( $\mathrm{Ctrl}(-)$ PCR). The PCR is representative of three independent experiments. (B) DNA precipitation assays were carried out using oligonucleotides containing a high affinity DR1 element (HA DR1, AGGTCAnAGGTCA, positive control), the DR0-like element and the DR3 element from the Ins/3 promoter either WT or with a mutation that destroys the binding site (Mut) along with nuclear extracts from MA-10 Leydig cells. Western blottings were used to detect COUP-TFII. Input corresponds to $15 \mu \mathrm{g}$ of the nuclear extracts used in the DNA precipitation assay. The western blotting shown is the representative of three independent experiments.

identified (Zimmermann et al. 1998, Koskimies et al. 2002). Mutagenesis studies showed that all three SF1 elements were needed for maximal SF1-dependent activation of the Insl3 promoter. However, SF1 displayed differential binding affinities for the three SF1 elements and was found to have the highest affinity for the most distal element at -144 to $-136 \mathrm{bp}$ (which represents a half-site of the DR3 we have identified in our study; Koskimies et al. 2002). Yet it was the element at -115 to $-107 \mathrm{bp}$ that showed the strongest response to SF1 in terms of transcriptional activation (Koskimies et al. 2002). In addition to the mice and rat Insl3 promoter, SF1 was also identified as a potent activator of the canine INSL3 promoter (Truong et al. 2003). Binding of SF1 to each site may very well differ in intensity between species as shown by Sadeghian et al. (2005), but the motif at -115 to -107 bp was always found to be critical for Insl3 gene expression in all species analysed (Zimmermann et al. 1998, Koskimies et al. 2002, Truong et al. 2003, Sadeghian et al. 2005, Robert et al. 2006). In addition to SF1, our laboratory has identified the orphan nuclear receptor NUR77 as a positive regulator of human and mice INSL3 transcription in Leydig cells. NUR77 was found to bind to an element located at $-100 \mathrm{bp}$ within the proximal INSL3 promoter, an element essential and sufficient to confer NUR77 responsiveness (Robert et al. 2006).

In our present work, we found that the orphan nuclear receptor COUP-TFII was essential for maximal Insl3 expression in MA-10 Leydig cells. Our results complement the in vivo findings by Qin et al. (2008) which showed that Insl3 mRNA levels were decreased in Coup-tfii ${ }^{-1-}$ mice at the pre-pubertal stage. However, as Leydig cell differentiation was impaired in these animals, it remained unknown whether the decrease in Insl3 was due to improper Leydig cell differentiation and/or to a direct action of COUP-TFII in Insl3 transcription. The fact that depletion of COUP-TFII in MA-10 Leydig cells using siRNA led to a significant decrease in Insl3 mRNA levels indicates that COUP-TFII could directly regulate Insl3 gene expression in these cells. This is further supported by the

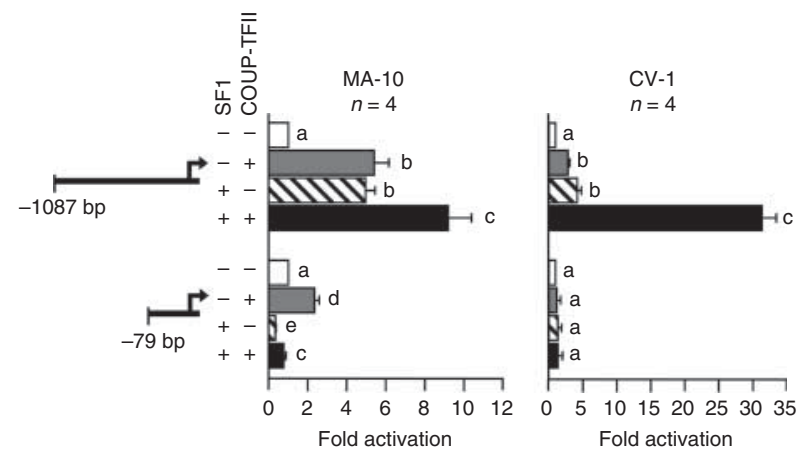

\section{Figure 8}

COUP-TFII and SF1 cooperate on the Ins/3 promoter. MA-10 Leydig (left panel) and CV-1 (right panel) cells were co-transfected with an empty expression vector (open bars) or expression vectors for COUP-TFII (grey bars) and SF1 (hatched bars) either alone or in combination (solid bars) along with $\mathrm{a}-1087 \mathrm{bp}$ and a $-79 \mathrm{bp}$ Ins/3 reporter. The number of experiments, each carried out in triplicate, is indicated. Results are shown as fold activation over control ( \pm S.E.M.). Different letters indicate statistically significant differences $(P<0.05)$.

Published by Bioscientifica Ltd. 
fact that COUP-TFII and INSL3 co-localise in Leydig cells of the adult mouse testis. In foetal testis, however, COUPTFII is not present in INSL3 positive cells, indicating that this nuclear receptor does not directly regulate Insl3 expression in the foetal testis.

A previously uncharacterised DRO-like sequence (GAGCCTCGACCT) was identified for COUP-TFII binding and promoter activation in the proximal Insl3 promoter, the region known to be sufficient for the Insl3 promoter activity (Zimmermann et al. 1998, Koskimies et al. 2002, Sadeghian et al. 2005). This DR0-like sequence at $-97 \mathrm{bp}$ was also present in the Insl3 promoter from various species including mice, rat, human and bovine, and thus has been evolutionarily conserved supporting a crucial function for the associated DNA-binding protein. Consistent with this, the human and rat Insl3 promoter were also significantly activated by COUP-TFII.

COUP-TFII is known to bind to a variety of DR elements with variable spacing. Although it shows the highest affinity for a DR1 element, COUP-TFII can also bind to DR0 and DR2 elements with the second highest affinity (Cooney et al. 1992, Kadowaki et al. 1992, Kliewer et al. 1992). Mutation of the DR0-like element severely decreased Insl3 promoter activity in MA-10 Leydig cells thus identifying this element as critical for Insl3 transcription. Furthermore, DNA-protein interaction experiments revealed that COUP-TFII binds to the DRO-like element. Yet, mutation in the DRO-like element that prevents COUPTFII binding had no effect on COUP-TFII-dependent activation of the Insl3 promoter in MA-10 Leydig cells. However, the same mutation abrogated COUP-TFIIresponsiveness of the Insl3 promoter in heterologous CV-1 fibroblast cells. These results indicated that although COUP-TFII can bind to and activate the Insl 3 promoter via the DRO-like element, it may also do so in a DNA bindingindependent manner most likely via interactions with other Leydig cell-enriched, DNA-bound transcription factors. The proximity of the SF1 binding site within the DR3 element, which is also important for Insl3 promoter activity in Leydig cells (this study and Koskimies et al. (2002)), prompted us to test whether COUP-TFII and SF1 function together on the Insl3 promoter. We found that COUP-TFII and SF1 had additive effects on Insl3 promoter activity when transfected in MA-10 Leydig cells whereas in CV-1 heterologous cells, the nuclear receptors had strong synergistic effects. This is the first report of a transcriptional cooperation between COUP-TFII and SF1. Additional work is needed to fully decipher the mechanisms of COUP-TFII and SF1 cooperation in Insl3 gene expression.
In conclusion, we reported that Insl3 mRNA levels were decreased in COUP-TFII-depleted MA-10 Leydig cells and found that the Insl3 promoter is directly and positively regulated by COUP-TFII. Furthermore, we identified a transcriptional cooperation between the nuclear receptors COUP-TFII and SF1 to further enhance Insl3 promoter activity. It is noteworthy that the concentration of INSL3 circulating in the bloodstream parallels the mRNA levels found within the testes (Irving-Rodgers et al. 2002, Ivell et al. 2013b) further supporting that this hormone is constitutively secreted as soon as it is synthesised. For this reason, quantification of Insl3 mRNA levels in the testis, or of INSL3 as the secreted peptide circulating in the bloodstream, provides an excellent assessment of Leydig cell differentiation and function (Ivell et al. 2013a). Our findings contribute to a better understanding of the regulation of INSL3 expression, a hormone now considered as an informative clinical parameter of gonadal function (Ivell et al. 2013a).

\section{Declaration of interest}

The authors declare that there is no conflict of interest that could be perceived as prejudicing the impartiality of the research reported.

\section{Funding}

R E M-V is the recipient of a doctoral studentship from the Réseau Québécois en Reproduction. J J T holds a Chercheur-Boursier Scholarship from the Fonds de Recherche du Québec - Santé. This work was funded by grants from the Canadian Institutes of Health Research (funding reference number MOP-81387) and from the Natural Sciences and Engineering Research Council of Canada (funding reference number 262224) to J J T.

\section{Acknowledgements}

The authors thank Drs Ming Tsai and Mario Ascoli for generously providing the COUP-TFII expression plasmid and the MA-10 cell line used in this study. They also thank Eric Boucher for his technical assistance with animal tissues and Caroline Daems for an Ins/3 promoter construct.

\section{References}

Adham IM, Burkhardt E, Benahmed M \& Engel W 1993 Cloning of a cDNA for a novel insulin-like peptide of the testicular Leydig cells. Journal of Biological Chemistry 268 26668-26672.

Adham IM, Steding G, Thamm T, Bullesbach EE, Schwabe C, Paprotta I \& Engel W 2002 The overexpression of the insl3 in female mice causes descent of the ovaries. Molecular Endocrinology 16 244-252. (doi:10.1210/mend.16.2.0772)

Amory JK, Page ST, Anawalt BD, Coviello AD, Matsumoto AM \& Bremner WJ 2007 Elevated end-of-treatment serum INSL3 is associated with failure to completely suppress spermatogenesis in men receiving male hormonal contraception. Journal of Andrology 28 548-554. (doi:10.2164/jandrol.106.002345) 
Anand-Ivell R, Wohlgemuth J, Haren MT, Hope PJ, Hatzinikolas G, Wittert G \& Ivell R 2006 Peripheral INSL3 concentrations decline with age in a large population of Australian men. International Journal of Andrology 29 618-626. (doi:10.1111/j.1365-2605.2006.00714.x)

Ascoli M 1981 Characterization of several clonal lines of cultured Leydig tumor cells: gonadotropin receptors and steroidogenic responses. Endocrinology 108 88-95. (doi:10.1210/endo-108-1-88)

Atlantis E, Martin SA, Haren MT, O'Loughlin PD, Taylor AW, Anand-Ivell R, Ivell R \& Wittert GA 2009 Demographic, physical and lifestyle factors associated with androgen status: the Florey Adelaide Male Ageing Study (FAMAS). Clinical Endocrinology 71 261-272. (doi:10.1111/j.1365-2265. 2008.03463.x)

Balvers M, Spiess AN, Domagalski R, Hunt N, Kilic E, Mukhopadhyay AK, Hanks E, Charlton HM \& Ivell R 1998 Relaxin-like factor expression as a marker of differentiation in the mouse testis and ovary. Endocrinology 139 2960-2970. (doi:10.1210/endo.139.6.6046)

Bathgate R, Balvers M, Hunt N \& Ivell R 1996 Relaxin-like factor gene is highly expressed in the bovine ovary of the cycle and pregnancy: sequence and messenger ribonucleic acid analysis. Biology of Reproduction 55 1452-1457. (doi:10.1095/biolreprod55.6.1452)

Burkhardt E, Adham IM, Brosig B, Gastmann A, Mattei MG \& Engel W 1994 Structural organization of the porcine and human genes coding for a Leydig cell-specific insulin-like peptide (LEY I-L) and chromosomal localization of the human gene (INSL3). Genomics 20 13-19. (doi:10.1006/geno.1994.1121)

Cederroth CR, Schaad O, Descombes P, Chambon P, Vassalli JD \& Nef S 2007 Estrogen receptor $\alpha$ is a major contributor to estrogen-mediated fetal testis dysgenesis and cryptorchidism. Endocrinology 148 5507-5519. (doi:10.1210/en.2007-0689)

Cooney AJ, Tsai SY, O'Malley BW \& Tsai MJ 1992 Chicken ovalbumin upstream promoter transcription factor (COUP-TF) dimers bind to different GGTCA response elements, allowing COUP-TF to repress hormonal induction of the vitamin D3, thyroid hormone, and retinoic acid receptors. Molecular and Cellular Biology 12 4153-4163. (doi:10. 1128/MCB.12.9.4153)

Del Borgo MP, Hughes RA, Bathgate RA, Lin F, Kawamura K \& Wade JD 2006 Analogs of insulin-like peptide 3 (INSL3) B-chain are LGR8 antagonists in vitro and in vivo. Journal of Biological Chemistry $\mathbf{2 8 1}$ 13068-13074. (doi:10.1074/jbc.M600472200)

Ferlin A, Pepe A, Gianesello L, Garolla A, Feng S, Giannini S, Zaccolo M, Facciolli A, Morello R, Agoulnik AI et al. 2008 Mutations in the insulinlike factor 3 receptor are associated with osteoporosis. Journal of Bone and Mineral Research 23 683-693. (doi:10.1359/jbmr.080204)

Irving-Rodgers HF, Bathgate RA, Ivell R, Domagalski R \& Rodgers RJ 2002 Dynamic changes in the expression of relaxin-like factor (INSL3), cholesterol side-chain cleavage cytochrome $\mathrm{p} 450$, and $3 \beta$-hydroxysteroid dehydrogenase in bovine ovarian follicles during growth and atresia. Biology of Reproduction 66 934-943. (doi:10.1095/ biolreprod66.4.934)

Ivell R \& Anand-Ivell R 2009 Biology of insulin-like factor 3 in human reproduction. Human Reproduction Update 15 463-476. (doi:10.1093/ humupd/dmp011)

Ivell R \& Anand-Ivell R 2011 Biological role and clinical significance of insulin-like peptide 3. Current Opinion in Endocrinology, Diabetes, and Obesity 18 210-216. (doi:10.1097/MED.0b013e3283453fe6)

Ivell R, Wade JD \& Anand-Ivell R 2013 $a$ INSL3 as a biomarker of Leydig cell functionality. Biology of Reproduction 88 1-8. (doi:10.1095/biolreprod. 113.108969)

Ivell R, Heng K, Nicholson H \& Anand-Ivell R 2013b Brief maternal exposure of rats to the xenobiotics dibutyl phthalate or diethylstilbestrol alters adult-type Leydig cell development in male offspring. Asian Journal of Andrology 15 261-268. (doi:10.1038/ aja.2012.138)

Kadowaki Y, Toyoshima K \& Yamamoto T 1992 Ear3/COUP-TF binds most tightly to a response element with tandem repeat separated by one nucleotide. Biochemical and Biophysical Research Communications 183 492-498. (doi:10.1016/0006-291X(92)90509-J)

Kawamura K, Kumagai J, Sudo S, Chun SY, Pisarska M, Morita H, Toppari J, Fu P, Wade JD, Bathgate RA et al. 2004 Paracrine regulation of mammalian oocyte maturation and male germ cell survival. PNAS 101 7323-7328. (doi:10.1073/pnas.0307061101)

Kliewer SA, Umesono K, Heyman RA, Mangelsdorf DJ, Dyck JA \& Evans RM 1992 Retinoid X receptor-COUP-TF interactions modulate retinoic acid signaling. PNAS 89 1448-1452. (doi:10.1073/pnas.89.4.1448)

Klonisch T, Kauffold J, Steger K, Bergmann M, Leiser R, Fischer B \& Hombach-Klonisch S 2001 Canine relaxin-like factor: unique molecular structure and differential expression within reproductive tissues of the dog. Biology of Reproduction 64 442-450. (doi:10.1095/ biolreprod64.2.442)

Koskimies P, Levallet J, Sipila P, Huhtaniemi I \& Poutanen M 2002 Murine relaxin-like factor promoter: functional characterization and regulation by transcription factors steroidogenic factor 1 and DAX-1. Endocrinology 143 909-919. (doi:10.1210/endo.143.3.8683)

Koskimies P, Suvanto M, Nokkala E, Huhtaniemi IT, McLuskey A, Themmen AP \& Poutanen M 2003 Female mice carrying a ubiquitin promoter-Insl3 transgene have descended ovaries and inguinal hernias but normal fertility. Molecular and Cellular Endocrinology 206 159-166. (doi:10.1016/S0303-7207(02)00425-2)

Kurihara I, Lee DK, Petit FG, Jeong J, Lee K, Lydon JP, DeMayo FJ, Tsai MJ \& Tsai SY 2007 COUP-TFII mediates progesterone regulation of uterine implantation by controlling ER activity. PLoS Genetics 3 e102. (doi:10.1371/journal.pgen.0030102)

Laguë E \& Tremblay JJ 2008 Antagonistic effects of testosterone and the endocrine disruptor mono-(2-ethylhexyl) phthalate on INSL3 transcription in Leydig cells. Endocrinology 149 4688-4694. (doi:10.1210/en.2008-0310)

Laguë E \& Tremblay JJ 2009 Estradiol represses insulin-like 3 expression and promoter activity in MA-10 Leydig cells. Toxicology 258 101-105. (doi:10.1016/j.tox.2009.01.013)

Lee CT, Li L, Takamoto N, Martin JF, Demayo FJ, Tsai MJ \& Tsai SY 2004 The nuclear orphan receptor COUP-TFII is required for limb and skeletal muscle development. Molecular and Cellular Biology 24 10835-10843. (doi:10.1128/MCB.24.24.10835-10843.2004)

Lin FJ, Qin J, Tang K, Tsai SY \& Tsai MJ 2011 Coup d'Etat: an orphan takes control. Endocrine Reviews 32 404-421. (doi:10.1210/er.2010-0021)

Martin LJ, Boucher N, Brousseau C \& Tremblay JJ 2008 The orphan nuclear receptor NUR77 regulates hormone-induced StAR transcription in Leydig cells through cooperation with $\mathrm{Ca}^{2+} /$ calmodulin-dependent protein kinase I. Molecular Endocrinology 22 2021-2037. (doi:10.1210/ me.2007-0370)

Martin LJ, Boucher N, El-Asmar B \& Tremblay JJ 2009 cAMP-induced expression of the orphan nuclear receptor Nur77 in MA-10 Leydig cells involves a CaMKI pathway. Journal of Andrology 30 134-145. (doi:10.2164/jandrol.108.006387)

Nef S \& Parada LF 1999 Cryptorchidism in mice mutant for Insl3. Nature Genetics 22 295-299. (doi:10.1038/10364)

Nef S, Shipman T \& Parada LF 2000 A molecular basis for estrogen-induced cryptorchidism. Developmental Biology 224 354-361. (doi:10.1006/ dbio.2000.9785)

O'Shaughnessy PJ, Willerton L \& Baker PJ 2002 Changes in Leydig cell gene expression during development in the mouse. Biology of Reproduction 66 966-975. (doi:10.1095/biolreprod66.4.966)

Paust HJ, Wessels J, Ivell R \& Mukhopadhyay AK 2002 The expression of the RLF/INSL3 gene is reduced in Leydig cells of the aging rat testis. Experimental Gerontology 37 1461-1467. (doi:10.1016/S05315565(02)00098-0)

Pereira FA, Qiu Y, Zhou G, Tsai MJ \& Tsai SY 1999 The orphan nuclear receptor COUP-TFII is required for angiogenesis and heart development. Genes and Development 13 1037-1049. (doi:10.1101/ gad.13.8.1037) 
Pereira FA, Tsai MJ \& Tsai SY 2000 COUP-TF orphan nuclear receptors in development and differentiation. Cellular and Molecular Life Sciences 57 1388-1398. (doi:10.1007/PL00000624)

Petit FG, Jamin SP, Kurihara I, Behringer RR, DeMayo FJ, Tsai MJ \& Tsai SY 2007 Deletion of the orphan nuclear receptor COUP-TFII in uterus leads to placental deficiency. PNAS 104 6293-6298. (doi:10.1073/ pnas.0702039104)

Pusch W, Balvers M \& Ivell R 1996 Molecular cloning and expression of the relaxin-like factor from the mouse testis. Endocrinology 137 3009-3013. (doi:10.1210/endo.137.7.8770925)

Qin J, Tsai MJ \& Tsai SY 2008 Essential roles of COUP-TFII in Leydig cell differentiation and male fertility. PLOS ONE 3 e3285. (doi:10.1371/ journal.pone.0003285)

Rahman NA \& Huhtaniemi IT 2004 Testicular cell lines. Molecular and Cellular Endocrinology 228 53-65. (doi:10.1016/j.mce.2003.05.001)

Robert NM, Martin LJ \& Tremblay JJ 2006 The orphan nuclear receptor NR4A1 regulates insulin-like 3 gene transcription in Leydig cells. Biology of Reproduction 74 322-330. (doi:10.1095/biolreprod.105.044560)

Sadeghian H, Anand-Ivell R, Balvers M, Relan V \& Ivell R 2005 Constitutive regulation of the Insl3 gene in rat Leydig cells. Molecular and Cellular Endocrinology 241 10-20. (doi:10.1016/j.mce.2005.03.017)

Spanel-Borowski K, Schafer I, Zimmermann S, Engel W \& Adham IM 2001 Increase in final stages of follicular atresia and premature decay of corpora lutea in Insl3-deficient mice. Molecular Reproduction and Development 58 281-286. (doi:10.1002/1098-2795(200103)58:3< 281::AID-MRD6 > 3.0.CO;2-0)

Spiess AN, Balvers M, Tena-Sempere M, Huhtaniemi I, Parry L \& Ivell R 1999 Structure and expression of the rat relaxin-like factor (RLF) gene. Molecular Reproduction and Development 54 319-325. (doi:10.1002/ (SICI)1098-2795(199912)54:4 < 319::AID-MRD1 > 3.0.CO;2-Z)

Strauss L, Kallio J, Desai N, Pakarinen P, Miettinen T, Gylling H, Albrecht M, Mäkelä S, Mayerhofer A \& Poutanen M 2009 Increased exposure to estrogens disturbs maturation, steroidogenesis, and cholesterol homeostasis via estrogen receptor $\alpha$ in adult mouse Leydig cells. Endocrinology 150 2865-2872. (doi:10.1210/en.2008-1311)

Takamoto N, You LR, Moses K, Chiang C, Zimmer WE, Schwartz RJ, DeMayo FJ, Tsai MJ \& Tsai SY 2005 COUP-TFII is essential for radial and anteroposterior patterning of the stomach. Development 132 2179-2189. (doi:10.1242/dev.01808)

Tremblay JJ \& Robert NM 2005 Role of nuclear receptors in INSL3 gene transcription in Leydig cells. Annals of the New York Academy of Sciences 1061 183-189. (doi:10.1196/annals.1336.020)

Tremblay JJ \& Viger RS 1999 Transcription factor GATA-4 enhances Mullerian inhibiting substance gene transcription through a direct interaction with the nuclear receptor SF-1. Molecular Endocrinology 13 1388-1401. (doi:10.1210/mend.13.8.0330)
Tremblay JJ \& Viger RS 2001 GATA factors differentially activate multiple gonadal promoters through conserved GATA regulatory elements. Endocrinology 142 977-986. (doi:10.1210/endo.142.3.7995)

Tremblay JJ, Robert NM \& Laguë E 2009 Nuclear receptors, testosterone, and posttranslational modifications in human INSL3 promoter activity in testicular Leydig cells. Annals of the New York Academy of Sciences 1160 205-212. (doi:10.1111/j.1749-6632.2008.03807.x)

Truong A, Bogatcheva NV, Schelling C, Dolf G \& Agoulnik AI 2003 Isolation and expression analysis of the canine insulin-like factor 3 gene. Biology of Reproduction 69 1658-1664. (doi:10.1095/biolreprod. 103.019166)

Tsai SY \& Tsai MJ 1997 Chick ovalbumin upstream promoter-transcription factors (COUP-TFs): coming of age. Endocrine Reviews 18 229-240. (doi:10.1210/edrv.18.2.0294)

You LR, Takamoto N, Yu CT, Tanaka T, Kodama T, Demayo FJ, Tsai SY \& Tsai MJ 2005 Mouse lacking COUP-TFII as an animal model of Bochdalek-type congenital diaphragmatic hernia. PNAS 102 16351-16356. (doi:10.1073/pnas.0507832102)

Zarreh-Hoshyari-Khah MR, Einspanier A \& Ivell R 1999 Differential splicing and expression of the relaxin-like factor gene in reproductive tissues of the marmoset monkey (Callithrix jacchus). Biology of Reproduction $\mathbf{6 0}$ 445-453. (doi:10.1095/biolreprod60.2.445)

Zhou W, Bolden-Tiller OU, Shetty G, Shao SH, Weng CC, Pakarinen P, Liu Z, Stivers DN \& Meistrich ML 2010 Changes in gene expression in somatic cells of rat testes resulting from hormonal modulation and radiationinduced germ cell depletion. Biology of Reproduction 82 54-65. (doi:10.1095/biolreprod.109.078048)

Zhou W, Bolden-Tiller OU, Shao SH, Weng CC, Shetty G, AbuElhija M, Pakarinen P, Huhtaniemi I, Momin AA, Wang J et al. 2011 Estrogenregulated genes in rat testes and their relationship to recovery of spermatogenesis after irradiation. Biology of Reproduction 85 823-833. (doi:10.1095/biolreprod.111.091611)

Zimmermann S, Schottler P, Engel W \& Adham IM 1997 Mouse Leydig insulin-like (Ley I-L) gene: structure and expression during testis and ovary development. Molecular Reproduction and Development 47 30-38. (doi:10.1002/(SICI)1098-2795(199705)47:1 <30::AID-MRD5 > 3.0. CO;2-R)

Zimmermann S, Schwarzler A, Buth S, Engel W \& Adham IM 1998 Transcription of the Leydig insulin-like gene is mediated by steroidogenic factor-1. Molecular Endocrinology 12 706-713. (doi:10.1210/ mend.12.5.0107)

Zimmermann S, Steding G, Emmen JM, Brinkmann AO, Nayernia K, Holstein AF, Engel W \& Adham IM 1999 Targeted disruption of the Insl3 gene causes bilateral cryptorchidism. Molecular Endocrinology 13 681-691. (doi:10.1210/mend.13.5.0272)

Received in final form 29 March 2014

Accepted 25 April 2014

Accepted Preprint published online 29 April 2014
() 2014 Society for Endocrinology Printed in Great Britain
Published by Bioscientifica Ltd 